\title{
ГРАММАТИЧЕСКИЕ ИНТЕРСЕКЦИИ ФОРМ ПРОШЕДШЕГО ВРЕМЕНИ В РАЗНОСТРУКТУРНЫХ ЯЗЫКАХ (НА МАТЕРИАЛАХ АНГЛИЙСКОГО И ТАТАРСКОГО ЯЗЫКОВ)
}

\author{
GRAMMATIC INTERSECTIONS OF PAST \\ TENSES IN NON-RELATED LANGUAGES \\ (ON THE MATERIALS OF ENGLISH \\ AND TATAR LANGUAGES) \\ V. Nasrtdinova \\ D. Zakirova
}

Summary: The authors of the article consider the semantic and functional intersections of the past tense forms on the materials of two non-related languages - English and Tatar. The paper describes the properties of two pairs of grammar tenses: Past Simple Tense - Билгеле үткән заман and Present Perfect Tense - Нәтижәле үткән заман, analyzing their didactic and heuristic potential for teaching English in a Tatar-speaking audience.

Keywords: non-related languages, past tenses, English language, Tatar language, grammar semantics.

\author{
Насртдинова Валентина Михайловна \\ К.ф.н., доцент, Казанское высшее танковое командное \\ училище \\ vmnasrtdinova@mail.ru \\ Закирова Диляра Борисовна \\ К.фрилол.н., старший преподаватель, Поволжская \\ академия физической культуры, спорта и туризма, \\ 2. Казань \\ zakirovadb@gmail.com
}

Аннотация: Авторы статьи рассматривают семантические и функциональные интерсекции (пересечения) форм прошедшего времени на материалах двух разноструктурных языков - английского и татарского. В работе описаны свойства двух пар временных форм: Past Simple Tense - Билгеле үткән заман и Present Perfect Tense - Нәтижәле үткән заман; а также проанализирован их дидактико-эвристический потенциал для преподавания английского языка в аудитории, владеющей татарским языком.

Ключевые слова: разноструктурные языки, формы прошедшего времени, английский язык, татарский язык, грамматическая семантика.
$\mathrm{B}$ Ыявление лингвистических интерсекций любой природы (лексико-грамматических, стилистических, фонетических и т.д.) в разноструктурных языках обладает выраженной прикладной значимостью и очевидным эвристическим потенциалом междисциплинарного характера. Так, проведение межъязыковых параллелей способно обеспечить не только дальнейшую аккумуляцию знания в области контрастивной лингвистики, но и существенный прогресс педагогических технологий, предоставляя преподавателям иностранных языков валидные методические инструменты.

Основанием обращения авторов к исследованию симилярных аспектов форм прошедшего времени в английском и татарском языках является поиск корректных экспланационных моделей для актуализации грамматики английского языка с учётом регионального компонента в Республике Татарстан. Для значительного количества обучающихся в ВУЗах республики родным является татарский язык, а владеет им, по некоторым оценкам, более 90\% студенческого контингента [5, с. 155]. Это означает, что использование исключительно русского языка в качестве опорно-иллюстративной языковой модели в ходе объяснения ряда аспектов английской грамматики не является в полной мере релевантным в силу лишь частичной трансляции семантических референций. Кроме того, посредничество русского языка способно, в некото- ром роде, даже осложнять изучение английского для учащихся-носителей татарского языка: так, например, В.М. Осипова отмечает, что «при понимании таких основополагающих аспектов грамматики английского языка, как времена Прошедшее простое (Past Simple) и Настоящее совершённое (Past Perfect) классически вызывающим затруднения является тот факт, что на русский язык оба времени переводятся как прошедшее, хотя в названии одного из них и звучит слово «Настоящее» [5, с. 155]. Анализируя когнитивную природу процесса изучения иностранного языка, В.Н. Хисамова прямо указывает на фактическую невозможность игнорировать строй и свойства родного языка обучающихся: «Овладение неродным языком формируется, как известно, на базе речевого опыта родного языка, и при обучении иностранному возникает необходимость сравнения систем родного и изучаемого языков» $[6$, с. 5$]$.

Использование татарского языка при изучении английской грамматики целесообразно не только для создания благоприятной психоэмоциональной обстановки в ходе реализации процесса обучения, но и с точки зрения наличия очевидных темпоральных и семантических аналогий между рядом грамматических форм названных языков.

В рамках настоящей работы рассмотрим грамма- 
тические интерсекции глагольных форм прошедших времён в английском и татарском языках.

Несмотря на то, что татарский и английский языки принадлежат к различным языковым семьям (тюркская и германская соответственно), а также существенно различаются типологически (аглийский - аналитический флективный язык, тогда как татарский - синтетический агглютативный); грамматические формы прошедшего времени в этих двух языках обнаруживают ряд схожих черт. Во-первых, в отличие, например, от русского языка, как татарский, так и английский языки располагают не фактически одним гомогенным глобально прошедшим временем, а целым спектром прошедших времён, обладающих своей фактологической, процессуальной, результирующей спецификой. Во-вторых, также в сравнении с русским языком, английский и татарский языки трансфер темпоральных градаций осуществляют графически-наглядно, средствами грамматики, с помощью глаголов-помощников и соответствующих флексий: did, had arrived, has seen, was doing (англ.); caтып алды, язып куйды, укыган, шалтыратканнар (тат.); тогда как в русском языке палитра хронологических уточнений выражается преимущественно лексическими средствами: до того, как, раньше, заранее, прежде, чем.

Традиционно, при изучении группы прошедших времён в английском языке первым рассматривается время Past Simple Tense (также Past Indefinite, простое прошедшее время). Функционально данная грамматическая форма обслуживает действия или события, которые произошли в определённое время в прошлом, а также описание последовательности действий в прошлом ("to talk about action or events that happened at a particular time in the past, to describe a series of actions or events in the past") [1, c. 166]. 'I left work at 10.30'. Jackson replied. 'I took a taxi home.' (Я вышел с работы в 10 часов 30 минут - omветил Джексон. Я взял такси до дома). Jackson put on his coat, switched off the light, opened the door and walked out onto the street. (Джексон надел свое пальто, выключил свет, открыл дверь и вышел на улицу)' [Там же].

Как семантически, так и прагматически, с точки зрения размещения коммуникативных интенций говорящего, время Билгеле үткән заман (прошедшее очевидное, также прошедшее категорическое) в татарском языке выступает ближайшим его аналогом - во-первых, это, как и Past Simple, наиболее употребимая глагольная форма, реферирующая к прошлому. Как указывает М. Н. Закамуллина, «Татарская временная форма Билгеле үткән заман , так называемая форма на -ды, в тюркских языках является самой распространенной формой про- шедшего времени» [4, с. 106]. Во-вторых, аналогично времени Past Indefinite, Билгеле үткән заман служит инструментом сообщения о завершенных действиях или событиях в завершённый отрезок времени в прошлом. Кызганычка каршы, алар кичә килмәделэр. (К сожалению, они вчера не приходили).

Әлбатта, ул миңа сезнең туган көнегез турында әйтmе. (Конечно, он рассказал мне о вашем дне рождения) $)^{2}$. Следующим немаловажным сходством является и то, что, так же, как и Past Simple Tense, глагольная форма Билгеле үткән заман способна обслуживать не только высказывания, констатирующие совершение сингулярных завершенных действий в прошлом, но и их последовательность: «В полипредикативном контексте татарская форма представляет последовательность действий/событий относительно друг друга, при этом каждое отдельно взятое действие представлено в своей целостности/глобальности...» [4, с. 107]. Ул жавап бирмәде, беркемне йортка чакырмады, тагын туганнарага шалmыратmы. (Она не дала ответа, никого не позвала в дом, потом позвонила родственникам) ${ }^{3}$.

Кроме того, анализируя современные коллоквиальные паттерны употребления обоих языков, следует обратить внимание на ещё одну сходную тенденцию: как в английском (особенно - в американском его варианте), так и в татарском языке наблюдается постепенная унификация и симплификация глагольных форм. И Past Simple, и Билгеле үткән заман приобретают статус ведущей для повседневного, неакадемического коммуницирования формы прошедшего времени. Применительно к английскому языку названный тренд уже зафиксирован и описан грамматистами: «In American English the past simple is often used instead of the present perfect simple, often with already and yet» [2] («в американском варианте английского языка простое прошедшее время зачастую употребляется вместо настоящего совершённого, часто со словами «ещё» и «уже»).

Авторами настоящей статьи не было обнаружено работ, посвященных рассмотрению упомянутого феномена в татарском языке, однако рабочая гипотеза о превалировании Билгеле үткән заман в разговорной речи была подтверждена на основании мини-опроса, проведенного в феврале 2021 года на личной странице В.М. Насртдиновой в социальной сети Instagram: $82 \%$ участников опроса указали, что наиболее востребованной в ежедневном общении является форма прошедшего времени на -ды/де, тогда как о частотном употреблении формы на -ган/-гән (Нәтижәле үткән заман, также Билгесез үткән заман) сообщают только 18\% респондентов, а

\footnotetext{
Здесь и далее перевод примеров приводится в редакции авторов.

Примеры: Насртдинова, Закирова.

Насртдинова, Закирова.
} 
иные существующие формы прошедшего времени (например, предпошедшее, или давнопрошедшее время) не были упомянуты ни одним из опрошенных.

Другой важной глагольной формой прошедшего времени для грамматики английского языка является временная форма Present Perfect Tense - настоящее совершённое время. Во многих классических учебниках по английской грамматике английского языка кроме модуля (юнита), посвящённого отдельному рассмотрению указанного времени, присутствует модуль, направленный на тренировку способности обучающихся корректно отличать случаи употребления Present Perfect oт Past Simple (см., например, Raymond Murphy English Grammar in Use, Cambridge, 2003; MyGrammarLab Intermediate, Pearson 2012). Трудности, связанные с дифференциацией данных временных форм, являют собой ингерентную специфику английской грамматики и никак не ассоциированы с исходным языковым бэкграундом учащихся. Впрочем, для носителей татарского языка эти трудности могут быть в значительной степени скомпенсированы. Дело в том, что в татарском языке существует ещё одна, уже упоминавшаяся выше, форма прошедшего времени: т. н. результативное прошедшее время, Нәтижәле үткән заман. Одной из ключевых характеристик обеих форм является наличие связи между прошлыми событиями и текущим моментом, причинно-следственный континуум между ранее совершенным действием и его результатами в настоящем. Сравним: «основное значение прошедшего результативного времени - Билгесез (Нәтижәле) үткән заман в татарском языке <...> - это перфективное значение, при реализации которого констатируется состояние, наступившее в результате прошлого действия и которое является актуальным для момента речи» [3, с. 20]; «we use the Present perfect simple to talk about recent past events that have a result in the present» (настоящее совершенное время используется для сообщения о недавних событиях в прошлом, имеющих результат в настоящем времени) [1, с.166]. Таким образом, опираясь на названные сходства, преподаватель английского языка может обращаться к примерам, доступным в татарском языке, актуализируя грамматическую семантику Present perfect tense; уместно приведение би- или трилингвальных примеров: Ask Ayrat, he has recently read this book (so that he knows the answer) - Айратка сорау бир, ул бу китапны укыган (димәк, ул жавап белә) - Спроси у Айрата, он прочитал эту книгу (и поэтому наверняка знает oтвет) $)^{4}$. Как показывает более чем десятилетний опыт работы в высшей школе каждого из авторов настоящей работы, такая экспланационная модель демонстрирует большую состоятельность, чем, например, простое теоретизированное указание на совершенный или несовершенный вид глагола в русском языке (Айрат читал Айрат прочитал).

Таким образом, установлено, что в рассмотренных разноструктурных языках - английском и татарском, наблюдаются интерсекции в семантике и коммуникативном функционале глагольных форм прошедшего времени, обладающие значительным эвристическим, когнитивным, дидактическим потенциалом для преподавания английского языка в татароговорящей среде. Кроме того, выявлено, что в обоих языках на современном этапе прослеживается общая тенденция универсализации форм прошедшего времени в неакадемическом, коллоквиальном дискурсе.

ЛИТЕРАТУРА

1. Davies, Paul A, Falla, Tim FCE Result Student's Book. Oxford University Press, 2008. 175 p.

2. Present perfect simple [Электронный ресурс] URL: https://dictionary.cambridge.org/grammar/british-grammar/present-perfect-simple-i-have-worked (дата обращения 02.02.2021)

3. Габдрахманова А.С. Грамматическая семантика и функциональные характеристики аспектуально-видовых форм прошедшего времени в татарском, турецком и английском языках: автореф. дис. ... канд. филол. наук. Чувашский государственный университет им. И.Н. Ульянова, Чебоксары, 2009.

4. Закамуллина М.Н. Глубинная структура, функционирование и референциальные особенности татарской формы билгеле уткән заман. Филологические науки. Вопросы теории и практики. Тамбов: Грамота, 2016. №12 (66): в 4-х ч. Ч. 3. С. 106 - 109.

5. Осипова В.М. Инкорпорация регионального компонента в качестве двигателя когнитивных процессов при актуализации некоторых аспектов грамматики английского языка. Лингвометодические проблемы преподавания иностранных языков в высшей школе: Межвуз. сб. науч. тр. / под ред. Н.И. Иголкиной. - Саратов: Изд-во Сарат. ун-та, 2011. - Вып. 8. - С. 154-155.

6. Хисамова В.Н. Глагольная система татарского языка в сравнении с английским языком: автореф. дис. ... д-ра филол. наук. Казан. гос. университет, Казань, 2005.

() Насртдинова Валентина Михайловна (vmnasrtdinova@mail.ru), Закирова Диляра Борисовна (zakirovadb@gmail.com).

Журнал «Современная наука: актуальные проблемы теории и практики»

4 Примеры: Насртдинова, Закирова. 